\title{
The price of development: The importance of preserving local agricultural lands
}

\author{
A. Rachelle Foss* \\ MacEwan University, Canada
}

\begin{abstract}
Regardless of the fact that we have long been warned of the negative impact of industrial farming, rural communities are being wiped out as local producers, like Riverbend Gardens, are put at risk in favour of urban expansion. The industrial food production industry is unsustainable, leading to increased energy consumption and food costs because of the gross use of energy to transport food hundreds kilometres from where it is produced. Toxic chemicals used to combat swarms of pests that are nurtured by acres of single crop farming have lead to the increase of these substances in our environment. The growing disconnection between ourselves and how our food is produced, fostered by diminishing farm communities, allows us to continue as we always have, until our current system collapses. This will have a deleterious effect on our health and our environment. Many of the answers to the problems we face in our food production industry lies in support for our small, local food producers. Located within Edmonton city limits, sustainable, family run, Riverbend Gardens, is at risk of being wiped out if government and consumers do not recognize the importance of small producers and their part in solving the food industry's failures.
\end{abstract}




\section{Introduction}

Nestled along the North Saskatchewan River, an old growth forest speckled with poplar and spruce presides over rows of vegetable plants that spring forth from the creased earth. There is something captivating about Riverbend Gardens. It may be the magic of an agricultural oasis in the boundaries of the Edmonton metropolis. Maybe it is the microclimate, created by the natural landscape, which supports perfect growing conditions (Messenger, 2013, para. 2-4). Or perhaps, it is that local producers like Riverbend Gardens “. . . are the essence of sustainability. . . . [They show us] it is possible for humans to feed themselves over a period of thousands of years, without exhausting the natural resources around them" (Elton, 2013, p. 255).

Whatever the magic is at Riverbend Gardens, this and other small, sustainable food producers are under the threat of being overlooked and steam-rolled by urban expansion over local business or the environment. It is important that we as a society recognize local producers as connected to the community, to the earth, and to part of the solution needed for reducing the impact the current food production industry has on our health and the environment.

\section{Unsustainable Energy Consumption and Increasing Costs}

Farming, which originally resembled small-scale producers like Riverbend Gardens, has attributed to the shape of contemporary society, and as noted by Dick and Taylor (2012), has enabled people to live in progressively larger groups (para. 1). But, as societies grew so grew the need to produce enough food to feed all the people within them (para. 1). This prompted the industrialization of agriculture and what has become an unsustainable food production industry. And we have long been aware that industrialized farming and much of our food production industry is unsustainable, unable to continue at the same rate or level.

A recent study commissioned by the UN found that "agriculture and food consumption are 'one of the most important drivers of environmental pressures" (Notras, 2010, para. 11). The World Watch Institute, which analyzes interdisciplinary environmental data worldwide to provide information for building a sustainable society, suggests that, "transporting food is one of the fastest-growing sources of greenhouse gas emissions" (Centre for Environmental Education, 2008, para. 1). This is a result of the "817 million tons of food ... shipped around the planet" (para. 1) each year, because "a basic diet of imported products can use four times the energy and produce four times the emissions of an equivalent domestic diet" (para. 1). In response to this information, people are being encouraged to buy locally produced food to reduce the energy used, 
often unnecessarily, in food transportation. However, if local growers continue to lose out to urban sprawl, there will be no local producers left to buy from.

\section{Unsustainable Exposure to Toxic Chemicals}

However, the UN is not the first to warn us of the negatives related to industrial agriculture. Rachel Carson warned in her book, Silent Spring, published in 1962, that "single-crop farming does not take advantage of the principles by which nature works; it is agriculture as an engineer might conceive it to be" as (p. 10). As such, this has lead to an increased need for pest control, which has a deleterious affect on both the environment and human health (Watts, 2008, para. 1). In comparison, "under primitive agricultural conditions the farmer had few insect problems. These arose with the intensification of agriculture - the devotion of immense acreages to a single crop. Such a system set the stage for explosive increases in specific insect populations" (Carson, 1962, p.10).

Rachel Carson (1962) also warned against the use of chemicals for pest control, like methyl parathion, which is "among the most poisonous chemicals in the world" (p. 27). The United States Environmental Protection Agency (1999) found that methyl parathion could not meet dosage requirements to be consumed safely over a seventy-year lifetime (para. 2). Yet, it was still "one of the most toxic and most widely used organophosphate pesticides" (para. 1), even though, according to Dr. Watts, there is a continuous, worldwide proposal to ban the deadly chemical (para. 3). This is especially concerning.

According to the report "Pesticides and Chemicals that Impact Agriculture"(n.d.), many pesticides are resistant to degradation, which translates to persistence in both the environment and in living things (p. 3). These chemicals don't remain where they are sprayed. Instead, they leak into "forests, rangeland, aquatic habitats" (Witford, Miller, Bennett, Jones, \& Bledsoe, n.d., para. 10), contaminating "ground water, surface water, rain, snow, fog, soil, vegetation and crops" ("Pesticides and Chemicals", n.d., p. 3). Thus, pesticides have become ubiquitous in the environment, exposing wildlife to toxic chemicals. According to Witford et. al, (n.d.) "acute poisoning to wildlife takes place over a relatively short time, impacts a very localized geographical area, and is linked to a single pesticide" (para. 11). Another negative affect of pest control is that it kills bees with as little discrimination as pest insects, which has disastrous implications for our future as "bees are credited with approximately 85 percent of the pollinating activity necessary to supply about one-third of the nation's food supply" (Stanford, 2013, para. 1).

In general, it is "worker bees are those primarily affected by pesticides" (Stanford, ECJ Volume 3, No. 1, 2013: The Voice of Change 
2013, para. 5). And although worker bees are on the front lines, they are not the only bees put at risk of being poisoned by pesticides: "some kill bees on contact in the field; others may cause brood damage or contaminate pollen, thus killing house bees" (para. 10). Researchers estimate that "nearly one-third of all honey bee colonies in the country have vanished" (Natural Resources Defense Council [NRDC], 2012, para. 3), and the suggested cause is a combination of issues, one of which is exposure to toxic pesticides (para. 4). Bees are necessary for agricultural and environmental processes to operate properly, and 'the list of crops that simply won't grow without honeybees is a long one: Apples, cucumbers, broccoli, onions, pumpkins, carrots, avocados, almonds ... and it goes on" (para. 1).

Recognizing the potential dangers to human health and the environment, the growers at Riverbend Gardens "take great care with our farming methods. We are responsible and cautious in our treatment of the land . . . using specific conventional treatments minimally and cautiously.” (Riverbend Gardens, 2013, para. 5, 7).

\section{Unsustainable Disconnect with Producers and our Food}

Considering the risks posed by our current food industry as it is, it is a wonder that so many people are still unaware of the importance of making changes to our food industry by supporting local producers as well as protecting and preserving their land from the threat of urban expansion, to ensure they continue operating.

This is important because not only does industrialized agriculture increase the distance our food travels it also decreases our connection to our food by taking it out of our awareness. This leaves many of us oblivious to the dangers we face if our food industry continues as it has been. The Slow Movement (2013), an organization that provides information and opportunities to encourage a sustainable way of life, sheds light on the fact that,

We are losing farmers every year, and rural communities are deteriorating socially and economically. Children are growing up not knowing where their food comes from - not just where it is produced but also how it is produced. Some children are unaware that carrots grow under the ground and tomatoes on plants above ground. They have lost connection to their food (para. 3).

This places focus on the importance of a relationship between community and local agriculture. The Hebert family, owners and operators of Riverbend Gardens, recognize the importance of a need to create a connection between the community and the land. 
In an "effort to develop an agricultural relationship with community members" (Riverbend Gardens, 2013, para. 1) they offer a variety of produce at farmer's markets across the Edmonton area. At their greenhouses they also offer U Pick Saskatoons for those who enjoy harvesting their own food, and for local backyard gardeners they grow a "variety of tomatoes suitable to the Edmonton climate" (Riverbend Gardens, 2013, para.3), as well as providing information and support on how to properly care for a garden. In addition to the local farmer's markets, Riverbend Gardens delivers fresh seasonal produce through the Community Supported Agriculture (CSA) program. According to CSA member, Elizabeth Bunney Lakoseljac, the program supports an agricultural relationship between Riverbend Gardens and the community, as CSA members "invest in their farm with the promise of receiving a bounty when the crops are ready" (Elizabeth interview, July, 15, 2013). And the benefits of such a relationship is not only one-sided. Elizabeth Bunney-Lakoseljac credits her involvement in the CSA as having improved and expanded her family's diet. "We have access to fresh vegetables every week and we find that we eat a lot more vegetables because of it. We are also eating things we hadn't used before, like kohlrabi and fennel. They taste so fresh everything tastes better than what is at the grocery store" (Elizabeth interview, July, 15, 2013).

But that is not where the community relationship ends. Riverbend Gardens also regularly provide fresh produce to local agencies such as the Mustard Seed church, as well as running fundraisers in support of their operation (Riverbend Gardens, 2013, para 1). The connection between Riverbend Gardens and all levels of the community run deep, and as such, preserving the land and the livelihood of this local producer should be paramount above the needs of urban sprawl.

\section{Conclusion}

Without community and government support towards movements for preserving agricultural land, small producers, like Riverbend Gardens, will continue to disappear until only industrialized single crop producers remain. The consequences of this put people and the environment at risk of continued exposure to chemical pesticides, increased food costs, and continued environmental pollution and degradation. Pushing out local farmers in favour of urban sprawl attributes to already rising food costs by reducing, if not almost eliminating people's choices for locally grown produce. This further contributes to the larger global food crisis by putting us at risk of being "only another US drought, South American drought or big episode in one of the main producers away from another big spike in food prices" (McGuiness, 2013, para. 20). 
* Author: A. Rachelle Foss is in her final year of the Professional Writing and Communications program at MacEwan University and has worked as an editor for both The Western Sentinel newspaper and NAIT. She has published articles in both the 2011 and 2012 editions of the Earth Common Journal. As an avid naturalist she draws inspiration from the environment.

\section{References}

Carson, Rachel. Silent Spring. Boston: The Riverside Press Cambridge, 1962. Print

Centre for Environmental Education. (2008). How School Food Affects the Environment.

Retrieved August 10, 2013, from

http://www.ceeonline.org/greenGuide/food/upload/environmenthealth.aspx

Dick, Lyle and Jeff Taylor. (2012). History of Agriculture. Historica Canada. Retrieved July 30, 2013, from http://www.thecanadianencyclopedia.com/articles/history-ofagriculture

Elton, Sarah. Consumed: Food for a Finite Planet. 2013. HarperCollins Publishers Ltd. Toronto, ON. Print

Health and Environmental Effects of Pesticides. (n.d.). Pdf. Retrieved July 27, 2013, from http://www.toronto.ca/health/hphe/pdf/ps_effects.pdf

Lucas, Caroline, Andy Jones, and Colin Hines. Peak Oil and Food Security: Fuelling a Food Crisis. Part One. (Winter 2007). Pacific Ecologist. Retrieved August 15, 2013, from <http://www.pacificecologist.org/archive/14/peak-oil>

McGuiness, Ross. (2013, April 13). Build a Sustainable Food Source: How Will We Feed 9 Billion People on the Planet in 2050. Metro News. Retrieved August 8, 2013, from http://metro.co.uk/2013/04/03/building-a-sustainable-food-source-howwill-we-feed-9-billion-people-on-the-planet-in-2050-3579801/

Messenger, Scott. (July 30, 2013). Paving Paradise. Avenue. Retrieved August 12, 2013, from http://www.avenueedmonton.com/articles/paving-paradise

Natural Resources Defense Council. (2008, July 25). V anishing Bees. Retrieved August 8, 2013, from http://www.nrdc.org/wildlife/animals/bees.asp

Notras, Mark. (2010, June 30). Agriculture and Food Sources

Unsustainable. Our World 2.0. United Nations University. Web Retrieved July 15, 2013, from 
http://ourworld.unu.edu/en/agriculture-and-food-systems-unsustainable/

Pesticides and Chemicals that Impact Agriculture. (n.d.). [Pdf Report]. Retrieved July 30, 2013, from http://www.diversifiedlaboratories.com/PestsandChemsAgr.pdf

Riverbend Gardens. (2013, Summer). About Us. Retrieved August 5, 2013, from http://www.riverbendgardens.ca/about.html

Riverbend Gardens. (2013, Summer). Home. Retrieved August 5, 2013, from http://www.riverbendgardens.ca/about.html

Riverbend Gardens. (2013, Summer). Products. Retrieved August 5, 2013, from http://www.riverbendgardens.ca/about.html

Slow Movement. (2013). What are Community Food Systems. Retrieved August 11, 2013, from http://www.slowmovement.com/cfs.php

Stanford, Malcolm, T., (2013). Protecting Honey Bees from Pesticides. Retrieved July 30, 2013, from http://edis.ifas.ufl.edu/aa145

United States Environmental Protection Agency. (1999, Aug 2). Metbyl Paratbion Risk Management Decision: Regulatory Actions. Retrieved March 18, 2011, from http://www.epa.gov/pesticides/factsheets/chemicals/mpfactsheet.htm

Watts, Meriel, Dr. (2008, October). Methyl Parathion Monograph. Pdf. Retrieved August 5, 2013, from http://www.panap.net/sites/default/files/monograph_methyl_parathion.pdf

Witford, Fred, Brian Miller, Richard Bennett, Margaret Jones, and Larry Bledsoe. (n.d.). Pesticides and Wildlife. Purdue Pesticide Programs. Retrieved August 10, 2013, from http://www.ppp.purdue.edu/Pubs/ppp30.html 